\title{
Experiences of Cement Industry in India
}

\author{
Vigneshwar Mekha ${ }^{1 *}$, Adma Kamalakar Reddy ${ }^{2}$ \\ ${ }^{I}$ Research scholar, Department of Geography, Osmania University, Hyderabad, India \\ ${ }^{2}$ Professor (Rtd), Department of Geography, Osmania University, Hyderabad, India
}

*Corresponding Author: Vigneshwar Mekha, Research scholar, Department of Geography, Osmania University, Hyderabad, India

\begin{abstract}
At present, the Indian Cement Industry (ICI) is spread all over the country, from north to south and east to west with most modern cement plants with latest technologies. There are about 84 large cement companies, which operate about 221 cement plants with an aggregate cement capacity of 444 million tonnes per annum (MTPA) as of 2015-16. The ICI plays a pivotal role in the national economy. It is a cyclical commodity with a high correlation with GDP, generating substantial revenue for government both state and central as well as a source of employment opportunities. Cement is the basic building material in India and is used extensively in urban housing, industrial sector and developing infrastructure. Consumption of cement is taken to be an indicator of economic development. The greater the infrastructure growth of a country, greater will be the consumption of cement. But nowadays ICI facing certain difficulties like under capacity utilization, inadequate machinery, operating cost, inefficiency of operations, infrastructure problems etc. The removal of these barriers can help the industry to the progress its performance in the future. The present study was designed to investigate the growth of ICI since 2011, in the terms of growth of plants, installed capacity, production, consumption as well as problems and prospects. This study is purely based on secondary data. The secondary data were collected for a period of 6 financial years (2011-2016) from the data base made available and maintained by various agencies, organizations, annual reports of companies etc for the purpose of periodical analysis of the industry. In order to effective study of ICI the technique of graphical presentation of data is used, which facilitates to understand the performance of the industry. In the end of the present study some implications and conclusion were incorporated.
\end{abstract}

Keywords: Trends, performance, industry, capacity, progress, analysis, prospects.

\section{INTRODUCTION}

Indian cement industry is a vital part of its economy, providing employment to more than a million populations. Even since it is deregulated in 1982, the Indian Cement Industry has attracted a lot of investment, making it the second largest producer in the world after china. It is been forecasted that the cement production in India grow at a CAGR of 9.7\% during the period 2007-17. Cement is a bonding agent that holds the concrete together and is therefore very important for meeting economy's needs of housing and accommodation and necessary infrastructure such as roads and bridges, schools, hospitals etc. Hence, this is one of the primary elements for locale up physically powerful and well infrastructure of the country and plays a pivotal role in financial progress and welfare of the country (source www.industrialchronicle.com). Major demand drivers for cement in India are housing and infrastructure sectors, commercial and industrial sectors (see chart 1).

Chart1: Major drivers of cement consumption in India

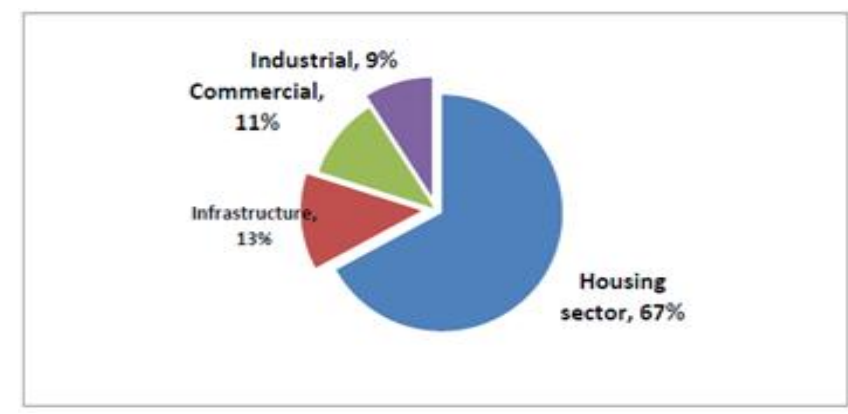

Source: IBEF, 2017 (Indian Brand Equity foundation) 
India is the second largest cement producer in the world after china with a capacity of 444 MT; it produced 283 MT as of 2015-16. There are a total of 586 plants out of which 221 are the larger ones. Further 188 large plants cover $97 \%$ of total installed capacity while 365 mini plants account for the balance.

\section{REVIEW OF LITERATURE}

The cement industry is an indigenous industry in which country is well endowed all types of necessary raw materials, skilled manpower, technology and know-how. Till now, there is no one comprehensive study to be carried out on the problems and prospects of cement industry in India. This paper makes a humble attempt to through some light on the previous relevant studies exists on cement industry in India.

Mehtha (1955) in a study on location quotient and coefficient of localization endeavored that the regionalization of cement firms clearly mirrors on account of the relative pull of industrious inputs. Poddar (1962 and 1966) in his two pioneer works on the Cement industry emphasized and enumerated all the historical facts associated to diverse aspects of Indian cement industry. Dogra (1980) studied an optimistic relationship between the growth of installed capacity, utilization of capacity and technological advancement of cement enterprises in India. Agarwal A.K. and Agarwal V.K (1986) made an attempt to examine the reasons and effects of capacity under utilization of cement industry in India based on the Mathematical and statistical techniques which covered all industries both the private sector and public sector cement industries.

\section{OBJECTIVES OF THE STUDY}

The research paper has the following principle objectives:

i. To study the trends in installed capacity and cement production of large cement plants in India.

ii. To find out the problems and prospects of cement industry in India

\section{Database And Methodology}

The present research paper is based on the secondary data. The important sources of secondary data are the reports of Cement Manufacturers Association, the survey of cement industry and Directory, reports of India Brand Equity Foundation, various journals, reports of planning commission and Cement Research Institute reports etc. The present study requires statistical based techniques percentages, averages and charts, graphs, diagrams are also used for graphical presentation of data.

\section{RESULTS AND DISCUSSION}

Cement industry is one of the major and oldest manufacturing industries in the modern sector of Indian economy. India is the second largest producer of cement in the world next only to china. The Indian cement industry also stands second in place in terms of consumption of cement, technology adoption and quality control.

\subsection{Geographical Segment wise Cement Installed Capacity}

As of 2015-16, India's total installed capacity is 444 Million Tonnes (MTs) and stood second largest cement producer in the world. Southern segment has the largest contribution in cement production of India and it has a largest capacity with 168 MTs followed by Northern Segment 88.24 MTs, Eastern segment 68.18 MTs, Western segment 62.52 MTs and Central segment 56.99 MTs (chart 2\&3). It is found from the study that Rajasthan state stands first with installed capacity of 60.30 MT, followed by Andhra Pradesh 60.02 MT, Tamilnadu 40.69 MT, Madya Pradesh 38.49, Karnataka 37.70, Maharastra 31.46 MT, Gujarath 31.06 MT and Telangana with 29.14 MT etc (table 1).

Table1: Region wise installed capacities of large cement plants in India.

\begin{tabular}{|l|l|l|l|}
\hline SEGMENT & Number of Plants & Percentage of Plants & Annual installed capacity 2015-16 \\
\hline NORTHERN & $\mathbf{4 1}$ & $\mathbf{1 8 . 5 5}$ & $\mathbf{8 8 . 2 4}$ \\
\hline HARYANA & 04 & 1.81 & 5.60 \\
PANJAB & 03 & 1.36 & 5.07 \\
RAJASTHAN & 22 & 9.95 & 60.30 \\
HIMACHAL PRADESH & 07 & 3.17 & 12.54 \\
DELHI & 00 & 0.00 & 0.00 \\
JAMMU \& KASHMIR & 02 & 0.90 & 0.73 \\
UTTARA KHAND & 03 & 1.36 & 4.00 \\
\hline EASTERN & $\mathbf{4 8}$ & $\mathbf{2 1 . 7 2}$ & $\mathbf{6 8 . 1 8}$ \\
\hline
\end{tabular}




\begin{tabular}{|c|l|l|l|}
\hline \multicolumn{2}{|l}{} \\
ASSAM & 05 & 2.26 & 4.41 \\
MEGHALAYA & 09 & 4.07 & 7.20 \\
BIHAR & 02 & 0.90 & 3.00 \\
JHARKHAND & 04 & 1.81 & 8.60 \\
ODISHA & 05 & 2.26 & 10.33 \\
WEST BENGAL & 13 & 5.88 & 14.06 \\
CHATTISHGARH & 10 & 4.52 & 20.58 \\
\hline SOUTHERN & $\mathbf{8 2}$ & $\mathbf{3 7 . 1 0}$ & $\mathbf{1 6 8 . 1 7}$ \\
\hline TELANGANA & 17 & 7.69 & 29.14 \\
ANDHRA PRADESH & 28 & 12.67 & 60.02 \\
TAMILNADU & 20 & 9.05 & 40.69 \\
KARNATAKA & 15 & 6.79 & 37.70 \\
KERALA & 02 & 0.90 & 0.62 \\
\hline WESTERN & $\mathbf{2 6}$ & $\mathbf{1 1 . 7 6}$ & $\mathbf{6 2 . 5 2}$ \\
\hline GUJARATH & 15 & 6.79 & 31.06 \\
MAHARASTRA & 11 & 4.98 & 31.46 \\
\hline CENTRAL & $\mathbf{2 4}$ & $\mathbf{1 0 . 8 6}$ & $\mathbf{5 6 . 9 9}$ \\
\hline MDHYRA PRADESH & 12 & 5.43 & 18.50 \\
GRAND TOTAL & 12 & 5.43 & 38.49 \\
\hline
\end{tabular}

Source: The Survey of Cement Industry and Directory, 2015.

Chart 2: Pie chart showing percentage of plants segment wise in India

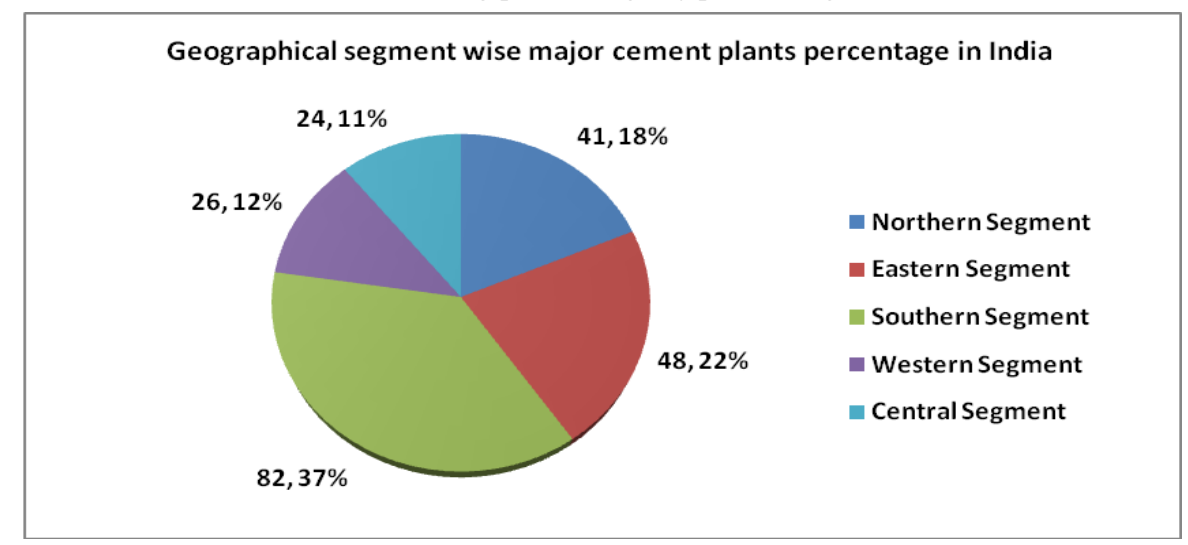

Source: The Survey of Cement Industry and Directory, 2015

Chart 3: Cement installed capacity of cement plants (in MTs) segment wise in India -2015-16

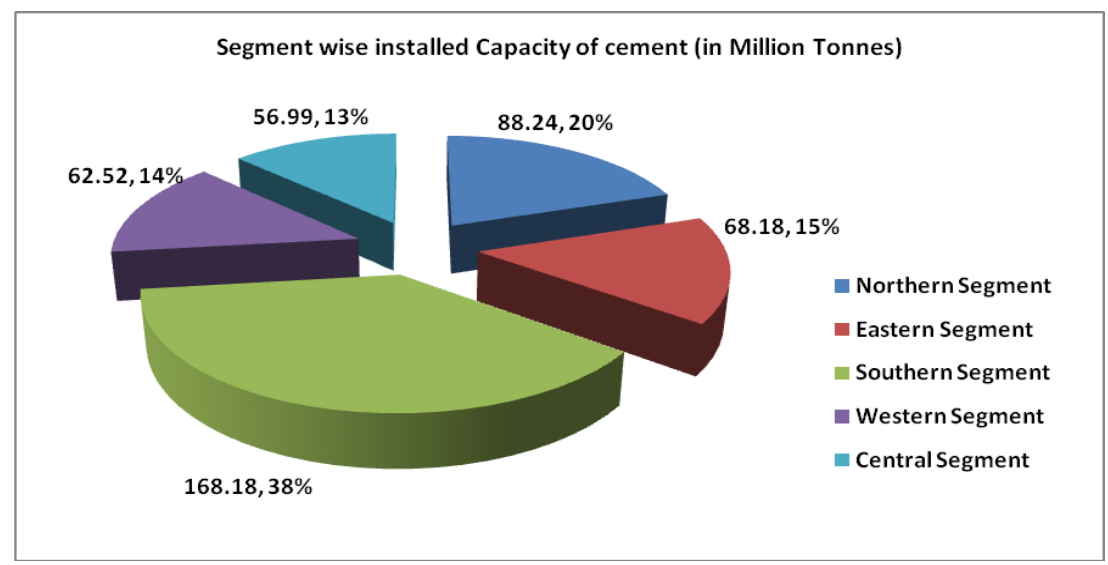

Source: The survey of Cement industry and Directory, 2015

\subsection{Cement Production scenario}

Capacity increased at a CAGR of 5.7\% from 323 MTPA in FY 2011 to 444 Mn tones in FY 2016. For the same period, production increased at a CAGR of 5.5\% from 216 MTs in 2011 to 283 MTs in 2016. Cement production grew by $4.62 \%$ in FY 2016 compared with $5.7 \%$ in FY 2015 and $3.06 \%$ in FY 2014 (table 2). Slower than envisaged economic and infrastructural activity, weakness in rural demand due to subdued monsoon and slowdown in real estate activity in large cities had impacted the growth rates of the industry in past few years. This along with surplus supply situation in the industry 
had impacted the capacity utilization rate adversely. However, green shoots of recovery were witnessed till October 2016 with cement production increasing by $4.8 \%$ for the period of April to October 2016 as against $2.9 \%$ for the same period last year. Relatively better and widespread monsoon this year was expected to have favorable impact on cement demand starting FY 2017.

Chart 4: Installed Capacity and Cement Production (in Million Tones) in India

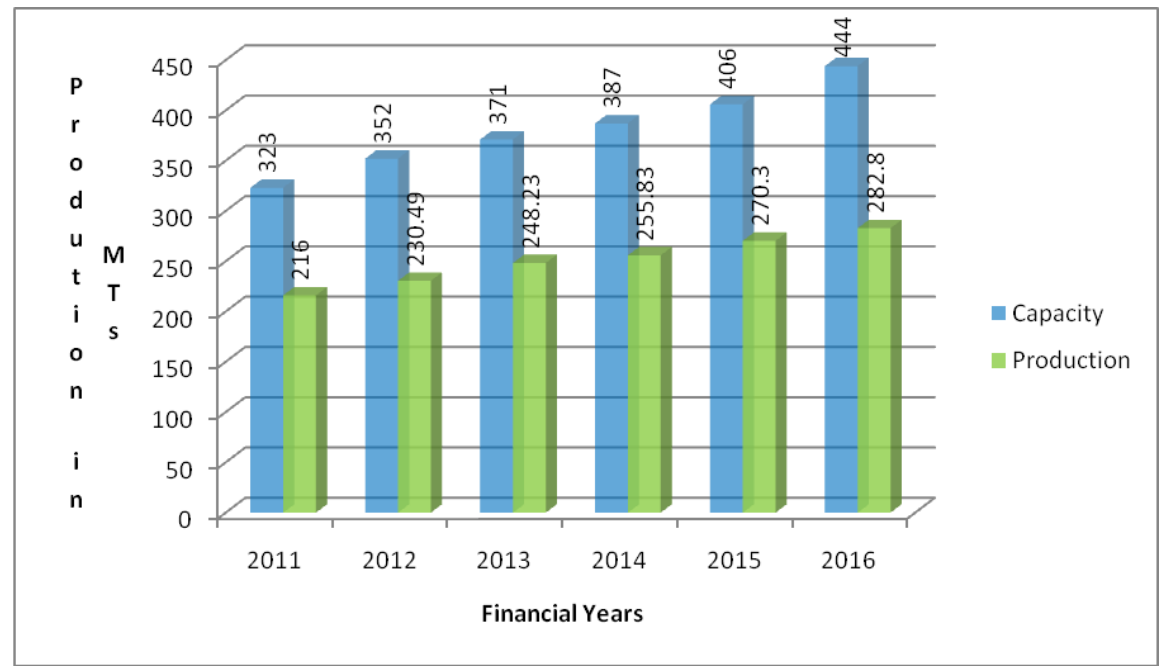

Source: Cement Manufacturers Association, 2016-17

In the recent years, the ICI is experiencing the entry of many Multi National Companies (MNCs) or foreign players in Indian market and entry of MNCs further boosted the growth of cement production. However, the ban on high currency denomination notes in November 2016 has impacted the demand growth of the industry. The demonetization system impacting housing and infrastructure sectors, more on trade including retail segment, the cement production/demand has declined after November 2016 and so far, based on the market sources dispatches and pricing stable to marginally down.

Table 2: Production and Growth of cement industry in India

\begin{tabular}{|l|l|l|l|l|}
\hline Year & Installed Capacity (in MTs) & Production (in MTs) & Growth (in MTs) & Growth rate (in \%) \\
\hline 2011 & 323 & 216.00 & 9.40 & $4.35 \%$ \\
\hline 2012 & 352 & 230.49 & 14.51 & $6.72 \%$ \\
\hline 2013 & 371 & 248.23 & 17.74 & $7.70 \%$ \\
\hline 2014 & 387 & 255.83 & 7.60 & $3.06 \%$ \\
\hline 2015 & 406 & 270.30 & 14.47 & $5.66 \%$ \\
\hline 2016 & 444 & 282.80 & 12.50 & $4.62 \%$ \\
\hline
\end{tabular}

Source: CMA \& IBEF January 2017

The consumption of cement grew at a CAGR of 5.4\% from 207 MTs in FY 2011 to 269 MTs in FY 2016. The consumption is further expected to increase at a CAGR of 15.7\% during 2011-2017 and reach 398 MTs. The demand will be supported by 2 and 3 tier cities. It is possible hence to say that had demonetization not been invoked, growth would have been pushed by the housing segment on the back of announcements made regarding PMAY-rural and housing for all by 2022, smart cities and various irrigation projects. The per capita consumption of cement in India is $190 \mathrm{~kg}$ in 2015 which is only about a third of the world average of over $350 \mathrm{~kg}$ per capita. It indicates the growth potential for this industry.

\section{Strengths And Problems Of Cement Industry}

The cement industry of Telangana state has been experiencing significant strengths and problems as the following :

\subsection{Strengths}

The following are the inborn and acquired strength of the Indian cement industry.

- Cement is basic and strategic industry to build the infrastructure of Indian economy.

- It is an important for the building houses that generates maximum employment in the economy

International Journal of Research in Geography (IJRG) 
- Cement industry contributes the exports and provide the profit of overseas exchange to country.

- Cement industry contributes in tax excise duties by which income of government is increased.

- Cement is a self-sufficient industry with negligible imports.

- Cement has no substitute.

- Fundamental technological progress in Indian cement industry has been insignificant since, more than 3 decades.

- Indian cement industry is concentrating in energy saving and distribution of cement bulk transportation.

\subsection{Problems of Indian Cement Industry}

The number of cement plants on the increase one side but another side those plants are suffering from lot of difficulties. Some major of them are;

\subsubsection{Inadequate Production}

The main factors responsible for shortfall in production are less superior and costly machinery, drastic power cuts ranging from 20 to $75 \%$ in various cement producing states, shortage of coal, inadequate availability of wagons and limited availability of furnace oil.

\subsubsection{Manufacturing Cost Problems}

The major raw materials for the cement industry are limestone, coal, power, dolomite and gypsum cement is a high cost industry as a result. Cement become frightening expensive costs, both manufacturing and non-manufacturing have gone up. Although the industry is largely under private sector, Government controls more than $40 \%$ of the cost. Power, coal and freight costs are all regulated by government bodies, such as, state Electricity Boards, Coal Monopolies and the Railways.

\subsubsection{Operational Inefficiency}

Operational inefficiency affects the cost of production operational inefficiency can be affected by the internal factors as well as external factors of the company.

\subsubsection{Operating Cost}

In the case of all other industries, there was a rise in the cost of cement production. But the special point is the case of cement industry was that some of the major cost rises were due to the government policies. The wagons shortage for the cement transport was always a serious issue. Power, coal and freight constitute about $15-20 \%$ each of the total cement cost while capital cost forms 20-30 percent.

\subsubsection{Less Supply of Cement}

The cement industry has recorded ample profits and growth and so has the construction industry. Going forward, the mega-infrastructure building impel and housing boom guarantee that the construction industry will continue to grow rapidly. The demand for cement will, therefore remain high because of the obvious linkages. There is an actual a demand and supply gap emerging. The cement industry doesn't have too much additional capacity and the commodity doesn't travel well either - So imports and inter-regional supplies are not easy to organize.

\subsubsection{Infrastructural Problems}

The fewer infrastructure facilities is one of the main problems faced by the cement industry. The infrastructure facilities mean the facilities of availability of adequate quantity and quality of coal, railway wagons regularity of power supply, sea-port, bridges, roads and canals, which is of very essential for optimizing capacity utilization in cement industry. It is because the cement plants are located in close proximity to the lime stone deposit regions, which are not appropriately linked with rail, road, power and communication services which affect to the cement industry.

\subsubsection{Policies and Regulations of Government}

The policies and regulations formulated by both state and central government not only encourage the industry but also have adversely affecting the cement industry. The various steps taken by government 
such as excise duty increase in railway fright, reduction in loading capacity of trucks, high electricity duty, sales tax, power tariff, demonetization etc negatively affects the cement industry.

\subsubsection{Administrative Problems}

Administrative problems include the workers problems, sales, distribution of cement, work environment and maintenance of safety measures problems etc.

\subsubsection{Low Per Capita Consumption of Cement}

The per capita consumption of the cement of the country is very low. It is $190 \mathrm{kgs} /$ year as compared to world average of $443 \mathrm{kgs}$ and $1683 \mathrm{kgs}$ of Saudi Arabia.

\subsubsection{Other Problems}

The other problems of cement industry in India include environmental problems, location problems, low export, under development of rural market etc.

\section{THE PROSPECTS}

The cement industry in India is facing certain barriers. The deletion of these barriers helps the industry in improving the performance further. The growth of the cement industry will be supported up by the following key drivers.

i. Increase in infrastructure investment

ii. Locating units nearer to markets

iii. Initiatives by the government

iv. Mergers and acquisitions

v. New investors and players

vi. Optimistic real estate market

vii. Changes in Technology

viii. Setting Captive power units

ix. Installation of pollution control measures etc.

\section{CONCLUSiON}

The cement industry occupies an important position in Indian economy. This is because of it is strongly linked with construction, transportation, industrial activity, bang in real estate business, mineral and power sectors etc., even though with rich raw materials, skilled labour, technical knowledge as well as favorable climate suitable for the industry. The industry is not reaching the level of self sufficiency and hope that will produce enough surpluses for export. It is possible hence to say that had demonetization not been invoked, growth would have been pushed by the housing segment on the back of announcements made regarding PMAY-rural and housing for all by 2022, smart cities and various irrigation projects and given the Central Government's thrust on housing and infrastructure development, cement demand is expected to pick up in the coming years.

\section{REFERENCES}

[1] Agarwal A.K. and Agarwal V.K., 1986, "Cement Industry in India - a critical study of Capacity Utilization", New Delhi: Common wealth Publishers, p. 11.

[2] Ahluwalia, I.J., 1991, Productivity and Growth in Indian Manufacturing, Oxford University Press,

[3] Archer, S.H., and Amboise C.L.A., 1972, "Business Finance; Theory and Management, Mc Millan company, New Yeak.

[4] Bangur H.M., 1980, $48^{\text {th }}$ Annual Session of Cement Manufacturers Association, New Delhi.

[5] Bhanu, V., 2007, "Indian Industries- A Study of Capacity Utilization, Growth, Structure and Profitability, Himalaya Publishing House, Mumbai.

[6] Bhayani S.J., "Practical Financial Statement Analysis", Raj book enterprise, Jaipur.

[7] Cement Manufacturers' Association, (CMA): Survey report (1994): Indian Cement Industry (Statistics), New Delhi, India. 
[8] Chopra, V.P., "The Location Pattern of Cement Industry, Institute of Economic Growth, New Delhi.

[9] Daily News and Analysis (DNA) 2006, Demand and supply gaping in cement, Sunday, May 14, New Delhi.

[10] Dogra, P.L., 1980, "Cement Industry in India”, a Ph.D thesis, University of Delhi, New Delhi.

[11] Goel V.K. and Nair N.K., 1978, "Productivity Trends I Cement Industry in India”, National Productivity Council, New Delhi.

[12] Indian Cement Industry Forecast to 2012, RNCOS online business research.

[13] K.D Gaur, P.J Meshram, K. L Shashidharam, Industries in Indian Economy, SARUP and SONS, pp. 2830.

[14] Katja Schumacher \& Jayant Sathaye, "India's Cement Industry: Productivity, Energy Efficiency and Carbon Emmission”, Environmental Energy Technologies Division.

[15] Mehta M.M, 1955, "Inter-relationship between Size, Location and Integration", Indian Economic Journal, April, pp. 144-149.

[16] Monthly Review of the Indian Economy, Feb 2012, No. 26-30.

[17] Nagaraja Rao, B.S., and Chandar K., 1980, Vol I \& II, “A Study of Cement Industry in India - Occasional Papers, Reserve Bank of India.

[18] NCAER, 1978, “Cement Industry in India - Problems and Prospects, National Council of Applied Economic Research, New Delhi.

[19] Poddar V., 1966, “Cement Industry Vol-I and Vol-II, Dalmianagar: Fohtas Industries”, pp 124-129.

[20] Ramaswamy, T., 2003, "Public Enterprise in India: Objectives and Performance", Himalaya Publishing House, Mumbai.

[21] Shilpa Choudary, 2008, "Impact of MNCs on Indian Cement Industry" ICFAI Journl of Management, Vol. VII, No. 3. Pp-20-25.

[22] Vijaya Raju, S., 1986, "Industrial Relations in Cement Industry of Coastal Andhra Pradesh - A Study of Workers Management and Union Management Relations, Ph.D thesis, Acharya Nagarjuna University, Guntur.

[23] www.ibef.org.

[24] www.Industrial chronicle.com

\section{AUTHOR'S BIOGRAPHY}

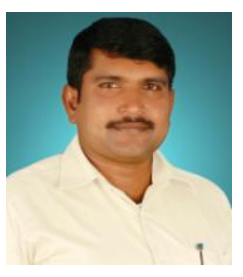

Vigneshwar Mekha is a Research Scholar, Department of Geography, Osmania University, Hyderabad. Also he has been working as a faculty of Geography for the last 15 years at Nagarjuna Government College (A), Nalgonda Dist, Telanagana state. He has been written three research articles which have appeared in reputed journals. At present, he has been working as writer of "Economic Geography" book which has to be published soon by Telugu Academy in Telangana state.

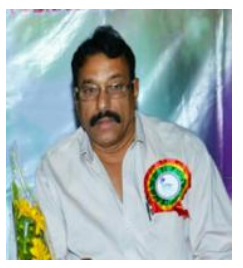

Dr. A. Kamalakar Reddy has been worked as a Professor and Head at Department of Geography, Osmania University, Hyderabad. He has been on the University faculty for the last 29 years and is actively engaged in research activities. A number of his research articles have appeared in reputed journals. Dr. A.K. Reddy has edited many social studies books of SCERT, which are being used as text books of state government schools of Telangana and Andhra Pradesh. He has written books on "Regional Geography of India' and 'Regional Geography of Andhra Pradesh' published by Telugu Academy, of Telangana and Andhra Pradesh which are using as text books at graduate level. Recently, he has been worked as an editor of Telugu Academy books namely "Economic Geography" and "Practical Geography" books, which are being used as text books at U.G level in Telangana State. More than 10 Research scholars have successfully completed their PhD under Dr. Reddy's supervision. He has successfully completed eight research projects in the department.

Citation: Vigneshwar Mekha, Adma Kamalakar Reddy. Experiences of Cement Industry in India. International Journal of Research in Geography. vol 4, no.2, 2018, pp. 72-78. doi: http://dx.doi.org/10.20431/ 2454-8685.0402007.

Copyright: (C) 2018 Authors. This is an open-access article distributed under the terms of the Creative Commons Attribution License, which permits unrestricted use, distribution, and reproduction in any medium, provided the original author and source are credited. 